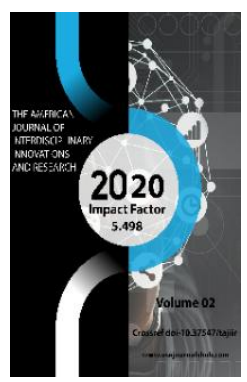

\title{
Reviews About Early Nomads In Central Asia
}

\author{
Umidulla Isar ugli Isarov \\ Teacher, Department of History of Uzbekistan and Source studies of Termez State University, \\ Uzbekistan
}

\footnotetext{
Journal Website: http://usajournalshub.c om/index,php/tajiir

Copyright: Original content from this work may be used under the terms of the creative commons attributes 4.0 licence.
}

\section{ABSTRACT}

It is well known that nomads have played an important role in World history. Central Asian nomads in particular also played a major and important role in the political life of the continent. In this article geography of Central Asian nomads' distribution, the system of political governance and social life of early nomadic tribes of Central Asia is analyzed.

\section{KEYWORDS}

Early nomads, Central Asia, Bronze age, nomadic tribes, Scythians, Saks, Massagets, Bactria, confederation, animal husbandry, Herodotus, historical geography of nomads.

\section{INTRODUCTION}

Central Asia is geographically one of the crossroads of ancient Eastern civilization and nomadic cultures. Ancient authors give many names of nomadic tribes living in Central Asia, especially in the Amudarya and Syrdarya basins, Fergana and adjacent mountainous areas, along the Aral Sea and in the desert and various sources give different information. This is due to the political associations of the nomadic peoples and the governance of the state. Because the composition of the tribal alliance formed by the nomads to protect their territories was different. These alliances were sometimes disbanded and reorganized. As some of the nomadic tribes left the political associations, their names and areas of residence also changed. Due to the large number of names and lifestyle similarities of Central Asian nomads, information about 
them can be found in various contradictory forms in historical sources.

\section{MAIN PART}

The main part of the geographical landscape of Central Asia is the steppe zone. The Amu Darya and Syr Darya, the largest rivers in Central Asia, start from mountain streams and join the steppe zone in the middle and lower part. Various nomadic tribes engaged in animal husbandry since ancient times have inhabited the area. Researcher V.M. Masson envisions a political map of Central Asia before the Achaemenids as follows: "Bactria had a large political union (state) who's cultural and political scope extended to Margiana, possibly to the Aryans and Sogdians. The second political force is the nomadic world. They had a confederation that united the various nomadic tribes. In the middle of the 6th century $\mathrm{BC}$, the Massaget tribes played a hegemonic role among the nomads".[4, p. 73]

The main form of ownership among the nomads was livestock. Pastures that grazed livestock were common in the early stages of community development. However, as a result of the increase in the number of livestock, pastures will also be divided among tribes or tribal allies. Water bodies are one of the main factors for feeding and breeding cattle. Nomads form armed guards or a group of warriors to guard pastures, cattle, and water bodies.

There are more than two social strata in nomadic communities. These rulers have a large herd and the poor communities who are in their service. The issues of family relations and social stratification of the first nomads of Central Asia are reflected in the Avesta [1, p. 137-139], in the works of ancient Greek historians. [2; 5, p. 84]
Regular contacts with the settled population and other nomadic tribes also played an important role in the formation of political associations among Central Asian nomads. Political associations formed by the nomadic tribes of Central Asia were formed on the basis of clear agreements and confederate rules. Their nomadic lifestyle has led to the slow development of this condition.

Political associations of Central Asian migrants were formed to protect their lands from neighboring tribes or invasions in the event of a serious military threat. Bright examples of this can be seen in the formation of huge political alliances during the military campaigns of the Achaemenid kings Cyrus II and Darius I, as well as Alexander the Great. The assassination of Cyrus, the defeat of Darius, the failure of Alexander the Great's military pressure in Central Asia to reach the lands of the nomads, or the cessation of the invasions marked the enormous political and military influence of the Central Asian nomadic confederations. [6, p. 164-170]

The factor influencing the subsequent duration of the union of tribes in the nomads is the confederate rules. In many cases, this violation of the terms of the treaty led to the rapid disintegration of the alliances. This means that the demand for new lands has been steadily increasing as a result of the increase in population among the tribes. To meet the need for new lands, the lands of neighboring tribes were occupied, the weak were squeezed out, and an alliance of nomadic tribes was formed to defend their lands or to organize large military campaigns.

These nomads inherited the right to "kingdom" from generation to generation. The role and status of women in governance and public life among Central Asian nomads 
was high. This can be seen as a manifestation of social equality.

At the head of each nomadic tribe stands a king or queen. Example: Queen Tomiris in Massagets, Princes Zarina in Saks, King Amorg, Queen Sparetra, and others. The king or queen also commanded the army during the war.

Ancient Greek historians recorded the multiplicity of nomadic kings. The reason for the multiplicity of kings is in the diversity of nations and tribes. Their election shows that the democratic ideas of the nomads have a high place in society.

Aristobulus wrote that ".... in the nomadic Scythians who lived on the banks of the river Tanais, kings were elected and he was given a staff (" skeptron "), a symbol of the kingdom by the river ...." [5, p. 84]. Strabo wrote, "... The nomads have two assemblies, one of which is a gathering of relatives, and the other of which is a gathering of sages and priests: the king may be elected from among the members of both congresses". [7, p. 93]

\section{RESULTS AND DISCUSSIONS}

There are many names of nomadic tribes living in the Central Asian regions and different sources. This can be seen as a situation related to the political associations of nomadic peoples and public administration. [3, p. 304.] Because the composition of the tribal alliance formed by the nomads to protect their territories was different.

Demodamus, the commander of Seleucus I and Antiochus, marched to the lands beyond the Syrdarya (300 BC) and information about the peoples there has been preserved. This march of the Seleucids, with the intention of expanding their territory, initially sent Demodam on a military expedition across the Syrdarya for reconnaissance purposes. According to the historian Pliny, as a result of the Demodamus marches many large tribes crossed the Syrdarya: Aryans, Rimniks, Peziks, Amards, Ists, Edons, Kons, Kaniaks, Evharis, Katyars, Antoisians, Psaks, Antakats, Khroazars, Oyks, Yaseys, Napeys. [8, p.27]

Based on the data of Avesto and ancient Greek historians, the names of the first nomadic tribes of Central Asia and their habitats are analyzed in Table 1. 
Table № 1. Names of Central Asian nomadic tribes and their location.

\begin{tabular}{|c|c|c|c|}
\hline № & Names of nomadic tribes & Living areas & Historical sources \\
\hline 1. & "Tur" tribes & In Central Asia & Avesto .Yasht. XVII. \\
\hline 2. & Danay" tribes & In Central Asia & Avesto .Yasht. V. \\
\hline 3. & "Sak" tribes & In Central Asia & $\begin{array}{l}\text { Herodotus. History. } \\
\text { I.131. }\end{array}$ \\
\hline 4. & "Tigrahauda" Saks tribes & In South Kazakhstan & $\begin{array}{l}\text { Herodotus. History. } \\
\text { I.131. }\end{array}$ \\
\hline 5. & "Haumavarga" saks tribes & $\begin{array}{l}\text { In mountainous areas of the } \\
\text { Pamirs and Southern Tianshan }\end{array}$ & $\begin{array}{l}\text { Herodotus. History. } \\
\text { I.133. }\end{array}$ \\
\hline 6. & "Tigradaraya" saks tribes & $\begin{array}{l}\text { In the middle reaches of the } \\
\text { Syrdarya. }\end{array}$ & $\begin{array}{l}\text { Herodotus. History. } \\
\text { I.132. }\end{array}$ \\
\hline 7. & "Overseas" saks tribes & $\begin{array}{l}\text { Around the Aral Sea, the lower } \\
\text { reaches of the Syr Darya, the } \\
\text { middle reaches and its shores. }\end{array}$ & $\begin{array}{l}\text { Herodotus. History. } \\
\text { I.150. }\end{array}$ \\
\hline 8. & "Orthocoribanti" tribes & unknown & $\begin{array}{l}\text { Herodotus. History. } \\
\text {.l.153. }\end{array}$ \\
\hline 9. & et" tribes & $\begin{array}{l}\text { The lower reaches of the } \\
\text { Amudarya and the Aral Sea, } \\
\text { according to some sources, in the } \\
\text { lower reaches of the Karakum } \\
\text { and Syrdarya }\end{array}$ & $\begin{array}{l}\text { Herodotus. History. } \\
\text { I.134. }\end{array}$ \\
\hline 10. & "Scythian" tribes & In Western Europe & $\begin{array}{l}\text { Herodotus. History. } \\
\text { I.131. }\end{array}$ \\
\hline 11. & “Amazon" tribes & $\begin{array}{l}\text { May be in the territories adjacent } \\
\text { to Khorezm (perhaps in the Aral } \\
\text { Sea and Amudarya delta) }\end{array}$ & $\begin{array}{l}\text { Herodotus. History. } \\
\text { IV } 110,115 .\end{array}$ \\
\hline 12. & $\begin{array}{l}\text { "Get" tribes } \\
\text { (Those who call } \\
\text { themselves immortal) }\end{array}$ & $\begin{array}{l}\text { In the lands before reaching Istra, } \\
\text { the western neighbor of the } \\
\text { Scythians }\end{array}$ & $\begin{array}{l}\text { Herodotus. History } \\
\text { IV. } 93 .\end{array}$ \\
\hline 13. & "Issedon" tribes & $\begin{array}{l}\text { To the east of the Girkans, around } \\
\text { the Murgab oasis }\end{array}$ & $\begin{array}{l}\text { Herodotus. History. } \\
\text { I.131. }\end{array}$ \\
\hline 14. & "Sakravl" tribes & $\begin{array}{l}\text { On the northern bank of the } \\
\text { Syrdarya }\end{array}$ & $\begin{array}{l}\text { Strabo. Geography. } \\
\mathrm{XI}, 8,2 \text {. }\end{array}$ \\
\hline 15. & "Adrasp" tribes & In areas adjacent to Massaget & Strabo. Geography. \\
\hline
\end{tabular}


The American Journal of Interdisciplinary Innovations and Research (ISSN-2642-7478)

Published: September 19, 2020 | Pages: 18-26

Doi: https://doi.org/10.37547/tajiir/Volume02Issue09-03

\begin{tabular}{|c|c|c|c|}
\hline & & $\begin{array}{l}\text { and Saks (may be around the Aral } \\
\text { Sea and Khorezm) }\end{array}$ & $\mathrm{XI}, 8,8$. \\
\hline 16. & “Azi” tribes & $\begin{array}{l}\text { On the northern bank of the } \\
\text { Syrdarya }\end{array}$ & $\begin{array}{l}\text { Strabo. Geography. } \\
\mathrm{XI}, 8,2 \text {. }\end{array}$ \\
\hline 17. & "Pasian" tribes & $\begin{array}{l}\text { On the northern bank of the } \\
\text { Syrdarya }\end{array}$ & $\begin{array}{l}\text { Strabo. Geography. } \\
\mathrm{XI}, 8,2 \text {. }\end{array}$ \\
\hline 18. & "Arakhot" tribes & $\begin{array}{l}\text { On the banks of the Ox (Amu } \\
\text { Darya), west of Bactria }\end{array}$ & $\begin{array}{l}\text { Strabo. Geography. } \\
\mathrm{XI}, 8 \text {. }\end{array}$ \\
\hline 19. & “Атасий “ лар & Contained in massaget tribes & $\begin{array}{l}\text { Strabo. Geography. } \\
\mathrm{XI}, 11,8 \text {. }\end{array}$ \\
\hline 20. & "Soil" saks tribes & unknown & $\begin{array}{l}\text { Quintus Curtius Ruf. } \\
\text { Histories of } \\
\text { Alexander the Great. } \\
\text { V,6-17. }\end{array}$ \\
\hline 21. & "Arakhozi" tribes & $\begin{array}{l}\text { On the banks of the Tanais } \\
\text { (Syrdarya) }\end{array}$ & $\begin{array}{l}\text { Quintus Curtius Ruf. } \\
\text { Histories of } \\
\text { Alexander the Great. } \\
\text { IV } 5,4 \text {. }\end{array}$ \\
\hline 22. & $\begin{array}{l}\text { "Pard" tribes (it could also } \\
\text { be the Persians) }\end{array}$ & $\begin{array}{l}\text { On the south coast of the } \\
\text { Amudarya }\end{array}$ & $\begin{array}{l}\text { Quintus Curtius Ruf. } \\
\text { Histories of } \\
\text { Alexander the Great. } \\
\text { V,6-17. }\end{array}$ \\
\hline 23. & "Mamasen" tribes & Between Kiropol and Tanais & $\begin{array}{l}\text { Quintus Curtius Ruf. } \\
\text { Histories of } \\
\text { Alexander the Great. } \\
\text { VII ,6-10. }\end{array}$ \\
\hline 24. & "Savromat" tribes & On the shores of the Aral Sea & $\begin{array}{l}\text { Quintus Curtius Ruf. } \\
\text { Histories of } \\
\text { Alexander the Great. } \\
\text { VII ,6-10. }\end{array}$ \\
\hline 25. & "Amurgiy" saks tribes & Between Bactria and India & $\begin{array}{l}\text { Arrian. The Anabasis } \\
\text { of Alexander, III. }\end{array}$ \\
\hline 26. & "Roksanaki" saks tribes & In Central Asia & $\begin{array}{l}\text { Arrian. The Anabasis } \\
\text { of Alexander. III. }\end{array}$ \\
\hline 27. & "Fastie" saks tribes & In Central Asia & $\begin{array}{l}\text { Arrian. The Anabasis } \\
\text { of Alexander. III. }\end{array}$ \\
\hline 28. & "Komedi" saks tribes & In Central Asia & Arrian. The Anabasis \\
\hline
\end{tabular}


The American Journal of Interdisciplinary Innovations and Research (ISSN-2642-7478)

Published: September 19, 2020 | Pages: 18-26

Doi: https://doi.org/10.37547/tajiir/Volume02Issue09-03

\begin{tabular}{|c|c|c|c|}
\hline & & & of Alexander. IV. \\
\hline 29. & "Komari" saks tribes & In Central Asia & $\begin{array}{l}\text { Arrian. The Anabasis } \\
\text { of Alexander. IV. }\end{array}$ \\
\hline 30. & "Karatti" saks tribes & In Central Asia & $\begin{array}{l}\text { Arrian. The Anabasis } \\
\text { of Alexander. IV. }\end{array}$ \\
\hline 31. & "Ariasp" tribes & $\begin{array}{l}\text { The southern neighbor of the } \\
\text { Scythians }\end{array}$ & $\begin{array}{l}\text { Arrian. The Anabasis } \\
\text { of Alexander. III. }\end{array}$ \\
\hline 32. & "Dai" tribes & $\begin{array}{l}\text { On the other side of Tanais } \\
\text { (Syrdarya) }\end{array}$ & $\begin{array}{l}\text { Arrian. The Anabasis } \\
\text { of Alexander. III, } 28 .\end{array}$ \\
\hline 33. & "Abi" tribes & On the other side of the Syrdarya & $\begin{array}{l}\text { Arrian. The Anabasis } \\
\text { of Alexander. IV,I }\end{array}$ \\
\hline 34. & "Kholh" tribes & $\begin{array}{l}\text { In the territories adjacent to } \\
\text { Khorezm, along the Aral Sea and } \\
\text { in the Amudarya delta }\end{array}$ & $\begin{array}{l}\text { Arrian. The Anabasis } \\
\text { of Alexander. IV,15. }\end{array}$ \\
\hline 35. & "Paratek" tribes & $\begin{array}{l}\text { In the territories adjacent to } \\
\text { Sogdia }\end{array}$ & $\begin{array}{l}\text { Arrian. The Anabasis } \\
\text { of Alexander. IV,21. }\end{array}$ \\
\hline 36. & "Auchasi" massaget tribes & unknown & $\begin{array}{l}\text { Arrian. The Anabasis } \\
\text { of Alexander. III. }\end{array}$ \\
\hline 37. & "Aparni" dai tribes & unknown & $\begin{array}{l}\text { Arrian. The Anabasis } \\
\text { of Alexander. III. }\end{array}$ \\
\hline 38. & "Apasiak" tribes & $\begin{array}{l}\text { Between Ox and Yaksart } \\
\text { (Amudarya and Syrdarya) }\end{array}$ & Polibius. X,48. \\
\hline 39. & "Debrik" tribes & $\begin{array}{l}\text { Lived in the Karakum Desert, the } \\
\text { northern neighbor of the Days }\end{array}$ & $\begin{array}{lr}\text { Diodorus } & \text { Siculus. } \\
\text { Historical Library. } \\
\text { Book II. Chapter } 2 .\end{array}$ \\
\hline 40. & "Arimasp" tribes & In the border areas with Hercania & $\begin{array}{ll}\text { Diodorus } & \text { Siculus. } \\
\text { Historical Library. } & \text { Chapter XVII, p.81. }\end{array}$ \\
\hline 41. & "Gidrozi" tribes & $\begin{array}{l}\text { In the border areas with the } \\
\text { country of Hyrcania }\end{array}$ & $\begin{array}{lr}\text { Diodorus } & \text { Siculus. } \\
\text { Historical Library. } \\
\text { Chapter VII, p.81. }\end{array}$ \\
\hline 42. & "Pazik" tribes & Near the Ox Mountains & $\begin{array}{l}\text { Ptolemy. } \\
\text { Geography. Book IV, } \\
12 .\end{array}$ \\
\hline 43. & "Yati" tribes & $\begin{array}{l}\text { In the northern part of the } \\
\text { Syrdarya }\end{array}$ & $\begin{array}{l}\text { Ptolemy. } \\
\text { Geography. Book IV, }\end{array}$ \\
\hline
\end{tabular}


The American Journal of Interdisciplinary Innovations and Research (ISSN-2642-7478)

Published: September 19, 2020 | Pages: 18-26

Doi: https://doi.org/10.37547/tajiir/Volume02Issue09-03

\begin{tabular}{|c|c|c|c|}
\hline & & & 12. \\
\hline 44. & "Oxiadrank" tribes & $\begin{array}{l}\text { At the foot of the Sogdian } \\
\text { mountains }\end{array}$ & $\begin{array}{l}\text { Ptolemy. } \\
\text { Geography. Book IV, } \\
12 .\end{array}$ \\
\hline 45. & "Dribakt" tribes & $\begin{array}{l}\text { At the foot of the Sogdian } \\
\text { mountains }\end{array}$ & $\begin{array}{l}\text { Ptolemy. } \\
\text { Geography. Book IV, } \\
12 \text {. }\end{array}$ \\
\hline 46. & "Kandar" tribes & $\begin{array}{l}\text { At the foot of the Sogdian } \\
\text { mountains }\end{array}$ & $\begin{array}{l}\text { Ptolemy. } \\
\text { Geography. Book IV, } \\
12 \text {. }\end{array}$ \\
\hline 47. & "Mardien" tribes & $\begin{array}{l}\text { At the foot of the Sogdian } \\
\text { mountains }\end{array}$ & $\begin{array}{l}\text { Ptolemy. } \\
\text { Geography. Book IV, } \\
12 .\end{array}$ \\
\hline 48. & “Oxien" tribes & $\begin{array}{l}\text { On the banks of the Ox } \\
\text { (Amudarya) }\end{array}$ & $\begin{array}{l}\text { Ptolemy. } \\
\text { Geography. Book IV, } \\
12 .\end{array}$ \\
\hline 49. & "Urapsian" tribes & $\begin{array}{l}\text { In the lower reaches of the } \\
\text { Amudarya and along the Aral Sea }\end{array}$ & $\begin{array}{l}\text { Ptolemy. } \\
\text { Geography. Book IV, } \\
12 \text {. }\end{array}$ \\
\hline 50. & "Aristi" tribes & $\begin{array}{l}\text { On the banks of the Tanais } \\
\text { (Syrdarya) }\end{array}$ & $\begin{array}{l}\text { Ptolemy. } \\
\text { Geography. Book IV, } \\
12 \text {. }\end{array}$ \\
\hline 51. & "Kirrodi" tribes & $\begin{array}{l}\text { On the banks of the Ox } \\
\text { (Amudarya) }\end{array}$ & $\begin{array}{l}\text { Ptolemy. } \\
\text { Geography. Book IV, } \\
12 \text {. }\end{array}$ \\
\hline 52. & "Orisp" tribes & In the south of Bactria & $\begin{array}{l}\text { Ptolemy. } \\
\text { Geography. Book IV, } \\
11 .\end{array}$ \\
\hline 53. & "Sabodi" tribes & In the south of Bactria & $\begin{array}{l}\text { Ptolemy. } \\
\text { Geography. Book IV, } \\
11 .\end{array}$ \\
\hline 54. & "Varn" tribes & In the south of Bactria & $\begin{array}{l}\text { Ptolemy. } \\
\text { Geography. Book IV, } \\
11 .\end{array}$ \\
\hline 55. & "Skord" tribes & In the south of Bactria & $\begin{array}{l}\text { Ptolemy. } \\
\text { Geography. Book IV, } \\
11 .\end{array}$ \\
\hline
\end{tabular}




\begin{tabular}{|l|l|l|l|}
\hline 56. & "Akinak" tribes & In the south of Bactria & $\begin{array}{l}\text { Ptolemy. } \\
\text { Geography. Book IV, } \\
11 .\end{array}$ \\
\hline 57. & "Kom" tribes & In the south of Bactria & $\begin{array}{l}\text { Ptolemy. } \\
\text { Geography. Book IV, } \\
11 .\end{array}$ \\
\hline 58. & "Khomar" tribes & In the south of Bactria & $\begin{array}{l}\text { Ptolemy. } \\
\text { Geography. Book IV, } \\
11 .\end{array}$ \\
\hline 59. & "Sagater" tribes & In Bactria & $\begin{array}{l}\text { Ptolemy. } \\
\text { Geography. Book IV, } \\
11 .\end{array}$ \\
\hline 60. & "Amarisp" tribes & In Bactria, north of Ox. & $\begin{array}{l}\text { Ptolemy. } \\
\text { Geography. Book IV, } \\
11 .\end{array}$ \\
\hline
\end{tabular}

Also, by analyzing the data on the first settlers of Central Asia, the boundaries of their habitats can be classified as follows:

1. Nomadic tribes living in areas with no definite borders (indefinite borders).

2. Nomads living in definite areas. (boundary definite, unchanged)

3. Nomads living in neighboring oases or in lands suitable for farming.

Of the above, the settlement of the tribes of the third group was relatively rapid. However, in the 6th century BC, Central Asian nomads formed military tribal alliances or political alliances to protect their lands from attack by other tribes.

Archaeological sources about the first settlers of Central Asia.

According to the results of research conducted so far, Central Asia is divided into the following regions according to the complex forms of material culture samples left by nomads:
1. The territory around the Aral Sea;

2. Ettisuv, Tien-Shan, Fergana and Pamir regions;

3. Tashkent oasis, middle reaches of the Syrdarya and coastal areas of Central Asian rivers;

4. Khorezm and the territories of northwestern Turkmenistan.

Archaeological excavations in the Aral Sea region began in the middle of the twentieth century. As a result of research conducted under the leadership of S.Tolstov, the culture of "Chirikrabod" was formed. [9, p. 127-142] The owners of the Chirikrabod culture, according to the scientist, are the Apasiak tribes.

We can also cite the Kuyusay culture, Tagisken, Uygarak and other archeological sites. Many settlements of the early nomads have also been studied in the Tien Shan and Yettisuv, Fergana and Pamir regions. In addition, as a result of research in the South Kazakhstan and Tashkent oases, the middle 
reaches of the Syrdarya and the rivers of Central Asia, the culture of "Kovunchi (I-II-III)" was introduced into science. Material sources studied in the monuments of nomads in Khorezm and northwestern Turkmenistan also give us reliable information about nomadic peoples.

\section{CONCLUSION}

Historical sources prove that the first nomadic tribes of Central Asia created a unique culture. Many nomadic tribes inhabited the steppe zones of Central Asia during the Bronze and Iron Ages. And they are united into confederations of different tribes. In particular, in the 6th century BC, a confederation of military tribes was formed in Central Asia by nomadic Sak-Massaget tribes to defend their lands. The study of these nomadic tribes is an actual issue in the science of history. Indeed, the study of these tribes may play a key role in the study of the ancient history of Central Asia.

\section{REFERENCES}

1. Boyce.A History of Zoroastrianism Vol III. Lieden: Brill, 1975. P. 137-139.

2. Herodotus. History. Book I.131.

3. Markov G.E. Nomads of Asia. The structure of the economy and social organization. M: Nauka, 1971, p. 304.
4. Masson V.M. Ancient agricultural culture of Margiana. MIA, 1959. - p. 73.

5. Pyankov I. V. The social structure of the early nomads of Central Asia according to the data of ancient authors. Early nomads of Central Asia and Kazakhstan. Leningrad, 1975 .-- p. 84.

6. Shaydullaev Sh. Emergence and stages of development of statehood in the territory of Uzbekistan (on the example of Bactria). dissertation for the degree of Doctor of Historical Sciences. Samarkand - 2009. p. 164170.

7. Strabo. Geography. Vol. IX-I. p 93.

8. Susan M. Sherwin-White, Amélie Kuhrt. From Samarkhand to Sardis: A New Approach to the Seleucid Empire. 1993. P.27

9. Tolstov S.P. The results of historical and archaeological research in 1961 on the ancient channels of the Syrdarya. S.A., 1962, No. 4, pp. 127-142.

10. Oblomurodov Naim Khalimovich, Ismatullayeva Nargiza Rasuljanovna, Goyibnazarov Isobek Shakarovich. The Purpose and Outcome of Diplomatic Missions in the II-I Centuries Between Central Asia And China. JCR. 2020; 7(9): 126-128. doi:10.31838/jcr.07.09.23 